\title{
Daya Tetas Telur Itik Cihateup dan Alabio
}

\author{
Cihateup and Alabio Duck Egg Hatchability \\ D. Darmawati ${ }^{1)}$, Rukmiasih' ${ }^{1)}$ \& R. Afnan ${ }^{1)}$ \\ ${ }^{1)}$ Departemen Ilmu Produksi dan Teknologi Peternakan, Fakultas Peternakan, Institut Pertanian Bogor \\ "Jln. Agatis, Kampus IPB Darmaga, Bogor16680
}

\begin{abstract}
Local ducks in Indonesia such as alabio duck and cihateup duck have advantages as egg producer and meat producer. Efforts is needed to increase the population of ducks by doing hatching. This research is to learn the hatchability of alabio duck and cihateup duck and identify of the factors that can be affected hatching duck eggs. Eggs ducks used 200 grains eggs ducks cihateup and eggs ducks alabio 300 grains. The process of hatching the egg ducks held for 28 days. The percentage fertility and hatchability results duck eggs alabio higher than cihateup duck eggs. Death embryonic the biggest occurred on the day to 26-28 days. Greater egg weights produce larger DOD. Weight of eggs and duck eggs index has no effect on hatchability but which affect hatchability of duck eggs in this study is high temperature during incubation, lower humidity during the period hatcher and egg hygiene. Alabio duck egg weight is lighter than duck eggs cihateup and more oval shaped while cihateup duck eggs more rounded shape. Weight egg and index egg on two types of eggs uniforms.
\end{abstract}

Keywords: alabio duck eggs, cihateup duck eggs, hatchability

\section{PENDAHULUAN}

Itik lokal di Indonesia menyebar dibeberapa daerah seperti di Jawa Barat dan Kalimantan Selatan. Itik lokal tersebut mempunyai keunggulannya masing-masing. Itik alabio yang dipelihara dan berkembang di Kalimantan Selatan terutama di Kabupaten Hulu Sungai Selatan (HSS), Hulu Sungai Tengah (HST), dan Hulu Sungai Utara (HSU) mempunyai keunggulan sebagai penghasil telur tetas dan telur konsumsi. Bila masa produksinya telah selesai atau pasca produksi. Itik-itik betina tersebut akan diafkir dan dijual sebagai itik potong (Supriadi 2011). Salah satu itik lokal yang berada di Jawa Barat adalah itik cihateup yang berkembang di daerah Cihateup Desa Rajamandala, Kecamatan Rajapolah, Kebupaten Tasikmalaya. Itik cihateup betina memiliki potensi sebagai penghasil telur, sedangkan itik cihateup jantan memiliki potensi sebagai penghasil daging dicirikan oleh ukuran lingkar dada yang lebih besar dibandingkan itik cirebon dan mojosari (Muzani 2005).

Populasi itik lokal tersebut pada tahun 2012 yaitu 46.989.522 ekor jauh lebih rendah dibandingkan ayam ras pedaging yaitu 1.266.902.718 ekor dan ayam ras petelur yaitu 130.539.437 ekor (Direktorat Jenderal Peternakan 2012), sehingga diperlukan upaya untuk meningkatkan populasi itik dengan menyediakan bibit itik yang baik dan unggul secara berkesinambungan. Penyediaan bibit itik dapat diperoleh dengan melakukan penetasan telur itik. Indikator keberhasilan proses penetasan dapat dicirikan oleh daya tetas. Daya tetas tersebut dipengaruhi oleh beberapa faktor diantaranya suhu, kelembaban, bobot telur, indeks dan kebersihan kerabang.

Tujuan penelitian ini adalah mengevaluasi daya tetas telur itik alabio yang berasal dari Kalimantan Selatan dan itik cihateup yang berasal dari Tasikmalaya, serta identifikasi faktor-faktor yang mempengaruhi penetasan telur itik dari kedua daerah yang berbeda tersebut.

Ruang lingkup penelitian ini adalah melakukan penetasan telur itik alabio dan telur itik cihateup, menentukan daya tetas dari kedua jenis telur itik tersebut serta mengidentifikasi faktor yang mempengaruhi daya tetas telur itik dari kedua daerah yang berbeda tersebut. Data berupa persentase fertilitas, daya tetas, dan kematian embrio dianalisis secara deskriptif. Data pendukung berupa bobot telur dan indeks telur dianalisis dengan T-tes. Data hubungan bobot telur dengan bobot tetas dianalisis dengan uji korelasi dan regresi.

\section{MATERI DAN METODE}

Penelitian ini dilakukan di Laboratorium Penetasan Telur Unggas, bagian Ilmu Produksi Teknologi Peternakan, Fakultas Peternakan Institut Pertanian Bogor. Bahan utama yang digunakan dalam penelitian adalah 300 butir telur itik alabio yang diperoleh dari peternakan itik di daerah Kalimantan Selatan dan 200 butir telur itik cihateup yang diperoleh dari peternakan di daerah Tasikmalaya. Pemeliharaan itik cihateup dilakukan secara ekstensif dengan rasio induk 1:10 (jantan:betina) dan umur induk sekitar 7 bulan. Itik alabio dipelihara secara 
intensif, rasio induk 1:10 (jantan:betina) dan umur induk sekitar 7 bulan. Bahan untuk sanitasi mesin tetas meliputi deterjen, disinfektan dan air. Bahan untuk fumigasi telur dan mesin tetas yaitu kalium permanganat $\left(\mathrm{KMnO}_{4}\right)$ dan formalin $40 \%$. Peralatan yang digunakan dalam penelitian ini meliputi mesin tetas otomatis, eggtray, candler, jangka sorong, timbangan digital, pita ukur, nampan, wadah untuk fumigasi, termometer (bola basah dan bola kering), termometer digital, pinset, cawan petri, gunting bedah, sprayer, amplas halus, dan gelas ukur. Bahan untuk sanitasi mesin tetas adalah deterjen, disinfektan dan air. Bahan untuk fumigasi telur dan mesin tetas yaitu PK (Kalium Permanganat $/ \mathrm{KMnO}_{4}$ ) dan formalin $40 \%$.

Metode penetasan telur itik diawali dengan sanitasi serta fumigasi mesin dan telur tetas setelah itu mengatur suhu dan kelembaban mesin tetas yaitu $37-38^{\circ} \mathrm{C}$ dan $60-$ $70 \%$. Penetasan telur itik dilakukan selama 28 hari. Selama proses penetasan dilakukan pemutaran, pendinginan dan pemeriksaan telur (candling). Pemutaran telur dilakukan 3 kali sehari dimulai pada hari ke-3 hingga hari ke-25 pengeraman. Pendinginan telur tersebut dilakukan 2 kali sehari yaiu pagi dan sore hari selama 15 menit dimulai pada hari ke-3 hingga hari ke-25 penetasan, pada hari ke-26 hingga hari ke-28 frekuensi pendinginan telur dilakukan sebanyak 3 kali yaitu pagi, sore dan malam hari. Peneropongan telur (candling) dilakukan untuk melihat keadaan telur dan perkembangan embrio selama proses inkubasi. Candling telur dilakukan 2 kali selama penetasan. Candling pertama pada hari ke-7 untuk penentuan telur fertil, fertil mati dan infertil (kosong). Telur fertil mati dan infertil dikeluarkan dari mesin tetas. Candling kedua pada hari ke-25 dilakukan untuk pendataan embrio yang mati dan pemindahan (transfer) telur fertil ke mesin penetasan (hatcher) dan dilakukan penimbangan bobot akhir telur. Setelah menetas, dilakukan pendataan jumlah telur yang menetas, dan telur yang gagal menetas. Telur-telur yang embrionya mati segera dikeluarkan dari mesin tetas, kemudian telur tersebut dipecah dan diperhatikan ciri-ciri embrio yang mati tersebut.

Peubah yang diamati antara lain daya tetas, fertilitas, indeks telur, bobot telur, dan kematian embrio. Data yang diperoleh kemudian diolah secara deskriptif. Nilai rataan, simpangan baku dan koefisien keragaman dari peubah yang diamati selama penetasan pada telur itik alabio dan telur itik cihateup, dihitung berdasarkan Mattjik dan Sumertajaya (2006).

$$
\begin{aligned}
\overline{\mathrm{X}}=\frac{\sum_{\mathrm{l}=1}^{\mathrm{N}} \mathrm{X}_{\mathrm{i}}}{\mathrm{N}} & =\frac{\mathrm{X}_{1}+\mathrm{X}_{2}+\mathrm{X}_{3}+\ldots+\mathrm{X}_{\mathrm{N}}}{\mathrm{N}} \\
\mathrm{SB} & =\sqrt{\frac{\sum_{\mathrm{i}=1}^{\mathrm{N}}\left(\mathrm{X}_{\mathrm{i}}-\overline{\mathrm{X}}\right)^{2}}{\mathrm{~N}-1}} \\
\mathrm{KK} & =\frac{\mathrm{SB}}{\overline{\overline{\mathrm{X}}} \times 100 \%}
\end{aligned}
$$

Keterangan :

$\overline{\mathrm{X}} \quad$ : Rata

$\mathrm{Xi} \quad$ : Data ke-i

$\mathrm{N} \quad$ : Banyak data

SB : Simpangan baku

KK : Koefisien keragaman

Analisis regresi linier dilakukan untuk mengetahui hubungan antara bobot telur dengan bobot tetas dan koefisien determinasinya untuk melihat besarnya hubungan tersebut (Steel dan Torrie, 1995). Model matematika yang digunakan:

Keterangan :

$$
\mathrm{Y}_{\mathrm{ij}}=\alpha+\beta \mathrm{X}_{\mathrm{i}}+€_{\mathrm{ij}}
$$

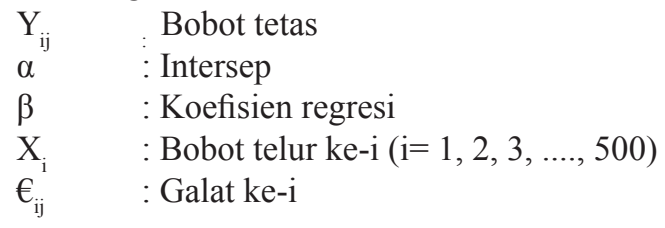

Uji T (t-Test) dilakukan untuk membandingkan jenis telur itik yang berbeda serta telur yang berhasil menetas dan telur yang tidak menetas. Model uji T yang digunakan menurut Steel dan Torrie (1995) adalah :

$$
\frac{x i-x j-D o}{\mathrm{~s} \sqrt{1 / n}+\sqrt{1 / n}}
$$

Keterangan :

$\begin{array}{ll}\mathrm{Xi} & \text { : Rata-rata perlakuan ke-i } \\ \mathrm{Xj} & \text { : Rata-rata perlakuan ke-j } \\ \mathrm{S} & \text { : Simpangan baku } \\ \mathrm{n} & \text { : Jumlah individu sampel } \\ \mathrm{Do} & \text { : Selisih } 2 \text { rataan yang berbeda }\end{array}$

Perhitungan indeks telur merupakan nilai persentase perbandingan antara lebar dan panjang telur. Fertilitas menunjukkan persentase telur yang fertil dari sejumlah telur yang ditetaskan dalam persen. Daya tetas merupakan perbandingan antara telur yang menetas dengan jumlah telur yang fertil dalam persen. Kematian embrio menunjukan persentase jumlah embrio yang mati dari telur yang fertil. Rumus untuk menghitung indeks telur, fertilitas, daya tetas, dan kematian embrio yaitu :

$$
\begin{aligned}
& \text { Indeks telur }=\frac{\text { lebar telur }}{\text { panjang telur }} \times 100 \% \\
& \text { Fertilitas }=\frac{\varepsilon \text { telur yang fertil }}{\varepsilon \text { telur yang ditetaskan }} \times 100 \% \\
& \text { Daya tetas }=\frac{\varepsilon \text { telur yang menetas }}{\varepsilon \text { telur yang fertil }} \times 100 \% \\
& \text { Kematian embrio }=\frac{\varepsilon \text { telur yang mati }}{\varepsilon \text { telur fertil }} \times 100 \%
\end{aligned}
$$

\section{HASIL DAN PEMBAHASAN}

\section{Fertilitas dan Daya Tetas Telur}

Persentase fertilitas dan daya tetas telur itik cihateup pada penelitian ini lebih rendah dari telur itik alabio. Persentase fertilitas telur dan daya tetas telur itik alabio dan telur itik cihateup disajikan pada Tabel 1.

Rendahnya persentase fertilitas telur itik cihateup diduga karena faktor perbedaan sistem pemeliharaan. Itik alabio dipelihara secara intensif sedangkan itik cihateup dipelihara secara ekstensif. Sistem pemeliharaan 
Tabel 1 Persentase fertilitas dan daya tetas telur itik alabio dan telur itik cihateup

\begin{tabular}{lccccc}
\hline Jenis telur itik & Jumlah telur (butir) & Telur yang fertil (butir) & Fertilitas (\%) & Telur yang menetas (butir) & Daya tetas (\%) \\
\hline alabio & 300 & 287 & 95,67 & 150 & 52,26 \\
cihateup & 200 & 149 & 74,50 & 32 & 21,48 \\
\hline
\end{tabular}

mempengaruhi proses perkawinan secara alami dan pakan. Sistem intensif itik dipelihara di dalam kandang yang sudah tersedia pakan dan minum sehingga asupan nutrisi yang diterima itik sesuai dengan kebutuhan. Proses perkawinan akan lebih mudah dilakukan karena itik jantan dan betina dipelihara dalam satu kandang yang memiliki luasan tertentu sehingga itik jantan lebih mudah untuk menjangkau itik betia. Pemeliharan secara ekstensif itik dipelihara di luar kandang (digembalakan) dan itik mencari makannya sendiri sehingga asupan nutrisi yang diterima itik sangat tergantung pada ketersediaan pakan di lahan penggembalaan. Proses perkawinan secara alami akan lebih sulit dilakukan karena itik jantan dan betina dilepas pada padang penggembalaan yang cukup luas biasanya pada daerah persawahan yang mengakibatkan itik jantan lebih sulit menjangkau itik betina karena area yang terlalu luas. Rendahnya persentase daya tetas telur itik cihateup disebabkan penanganan telur itik selama penyimpanan yang kurang baik dicirikan dari kondisi kerabang telur yang kotor sehingga dapat menurunkan daya tetas. Kondisi telur yang kotor memungkinkan peluang masuknya mikroorganisme ke dalam telur melalui pori-pori kerabang yang menyebabkan kematian embrio (Rohaeni et al. 2005).

Persentase fertilitas telur itik alabio pada penelitian ini hampir sama dengan penelitian yang dilakukan oleh Matitaputty (2012) sebesar 95,61\%, karena adanya persamaan pada sistem pemeliharaan. Fertilitas telur itik cihateup pada penelitian ini lebih rendah dari hasil penelitian yang dilakukan oleh Matitaputty (2012) sebesar 94,88\% dan Suretno (2006) sebesar 90,94\%. Hal tersebut kemungkinan disebabkan oleh perbedaan proses perkawinan. Penelitian ini menggunakan perkawinan alami sedangkan pada penelitian yang dilakukan Suretno (2006) dan Matitaputty (2012) menggunakan inseminasi buatan. Inseminasi buatan menyebabkan fertilitas yang tinggi karena spermatozoa tidak melalui seleksi alami yang ketat pada daerah vagina sehingga sperma tidak banyak yang mati (Gazali 2001). Hasil persentase daya tetas telur itik alabio pada penelitian ini lebih tinggi dari hasil penelitian yang dilakukan oleh Matitaputty (2012) sebesar 46,47\% karena perbedaan bibit itik yang digunakan untuk menghasilkan telur tetas. Hal tersebut sesuai dengan pendapat Lasmini et al. (1992) yang menyatakan daya tetas dapat dipengaruhi oleh faktor genetik dan faktor lingkungan. Persentase daya tetas telur itik cihateup pada penelitian ini rendah jika dibandingkan dengan hasil penelitian yang dilakukan oleh Matitaputty (2012) sebesar 30,48\%. Penyebab perbedaan daya tetas tersebut karena perbedaan kualitas telur tetas.

\section{Kematian Embrio}

Persentase kematian embrio tertinggi pada penelitian ini terjadi pada hari ke 26-28. Kematian embrio telur itik cihateup lebih tinggi dari telur itik alabio. Persentase kematian embrio selama penetasan disajikan pada Tabel 2.
Kematian embrio telur itik cihateup lebih tinggi dari telur itik alabio karena kondisi telur tetas itik cihateup lebih kotor dibandingkan telur itik alabio sehingga mikroorganisme mudah masuk ke dalam telur melalui poripori kerabang dan dapat menyebabkan kematian embrio. Hal tersebut sesuai dengan pendapat Setiadi et al. (1992) yang menyatakan tingginya tingkat kematian embrio salah satu diantaranya adalah faktor kebersihan telur. Embrio banyak yang mati di hari ke 26-28 karena suhu tinggi dan kelembaban rendah selama periode hatcher. Pada hari ke 26-28 atau periode hatcher merupakan masa kritis perkembangan embrio pada masa tersebut (hari ke 26-27) embrio berusaha untuk meretakkan kerabang (Fujiwati et al. 2012). Suhu yang tinggi menyababkan kematian embrio ataupun abnormalitas embrio sedangkan kelembaban mempengaruhi pertumbuhan normal dari embrio dan menjaga cairan dalam telur serta merapuhkan kerabang telur (Wulandari 2002). Suhu dan kelembaban mesin tetas selama proses penetasan disajikan pada Tabel 3.

Suhu dan kelembaban di dalam mesin tetas dicatat pada setiap periode penetasan pada pagi hari (pukul 07.00 WIB), siang hari (pukul 12.00 WIB), dan sore hari (pukul 17.00 WIB). Rataan suhu mesin setter hari ke 0-7, hari ke 8-25, dan hatcher hari ke 26-28 pada penelitian ini lebih tinggi dan tidak stabil dari yang disarankan Kortlang (1985) yaitu untuk periode setter suhu mesin tetas $37,3^{\circ} \mathrm{C}$ dan suhu mesin tetas periode hatcher adalah $36,3-36,7^{\circ} \mathrm{C}$. Kelembaban periode setter hari ke 0-7 dan 8-25 pada penelitian ini sudah sesuai dengan yang disarankan oleh Kortlang (1985) yaitu diatas $60 \%$, namun pada periode hatcher kelembaban mesin tetas lebih rendah dari yang disarankan Kortlang (1985) yaitu $80 \%-85 \%$. Pendapat tersebut sesuai dengan Nuryati et al. (2000) yang menyatakan kelembaban perlu dinaikan sampai $85 \%$ pada minggu terakhir menjelang menetas.

Embrio yang mati pada telur itik alabio dan cihateup memiliki ciri-ciri seperti telur busuk, terbentuk selaput darah, embrio terlihat lemah dan kering, bulu rontok, terdapat pula kelainan pada paruh, kepala, dan kaki. Ciriciri embrio yang mati pada telur itik alabio dan cihateup disajikan pada Tabel 4.

Embrio itik alabio dan itik cihateup yang mati pada penelitian ini memiliki ciri-ciri seperti sudah terbentuknya selaput darah, embrio lemah dan kering, kuning telur belum masuk ke dalam rongga perut (di luar), bulu rontok,

Tabel 2 Persentase kematian embrio selama penetasan

\begin{tabular}{lccc}
\hline \multirow{2}{*}{ Jenis telur } & \multicolumn{3}{c}{ Kematian embrio (\%) } \\
\cline { 2 - 4 } & Hari ke 0-7 & Hari ke 8-25 & Hari ke 26-28 \\
\hline Itik alabio & 9,06 & 6,27 & 32,40 \\
& $(\mathrm{n}=26$ butir $)$ & $(\mathrm{n}=18$ butir $)$ & $(\mathrm{n}=93$ butir $)$ \\
Itik cihateup & 15,44 & 20,81 & 42,28 \\
& $(\mathrm{n}=23$ butir $)$ & $(\mathrm{n}=31$ butir $)$ & $(\mathrm{n}=63$ butir $)$ \\
\hline
\end{tabular}


Tabel 3 Suhu dan kelembaban mesin tetas selama proses penetasan

\begin{tabular}{|c|c|c|c|c|c|c|c|c|}
\hline \multirow[t]{3}{*}{ Umur Penetasan } & \multicolumn{6}{|c|}{ Waktu } & & \\
\hline & \multicolumn{2}{|c|}{ Pagi } & \multicolumn{2}{|c|}{ Siang } & \multicolumn{2}{|c|}{ Sore } & \multicolumn{2}{|c|}{ Rata-rata } \\
\hline & $\left({ }^{\circ} \mathrm{C}\right)$ & $(\%)$ & $\left({ }^{\circ} \mathrm{C}\right)$ & $(\%)$ & $\left({ }^{\circ} \mathrm{C}\right)$ & $(\%)$ & $\left({ }^{\circ} \mathrm{C}\right)$ & $(\%)$ \\
\hline \multicolumn{9}{|l|}{ Setter } \\
\hline 0-7 hari & $37,7 \pm 0,5$ & $66,9 \pm 5,5$ & $38,0 \pm 0,0$ & $69,9 \pm 8,1$ & $38,0 \pm 0,0$ & $67,8 \pm 9,0$ & $37,8 \pm 0,2$ & $67,9 \pm 7,5$ \\
\hline $8-25$ hari & $38,0 \pm 0,0$ & $71,2 \pm 3,8$ & $36,4 \pm 2,6$ & $75,3 \pm 6,2$ & $38,0 \pm 0,0$ & $71,8 \pm 3,6$ & $37,6 \pm 0,9$ & $72,4 \pm 4,5$ \\
\hline \multicolumn{9}{|l|}{ Hatcher } \\
\hline 26-28 hari & $37,3 \pm 0,2$ & $75,5 \pm 3,8$ & $37,5 \pm 0,1$ & $76,0 \pm 4,3$ & $37,3 \pm 0,1$ & $76,7 \pm 3,0$ & $37,3 \pm 0,2$ & $75,9 \pm 3,7$ \\
\hline
\end{tabular}

Tabel 4 Ciri-ciri embrio yang mati pada telur itik alabio dan cihateup

\begin{tabular}{|c|c|c|c|c|}
\hline \multirow[t]{2}{*}{ Umur telur } & \multirow[t]{2}{*}{ Ciri-ciri embrio } & \multirow[t]{2}{*}{ Penyebab kematian } & \multicolumn{2}{|c|}{ Mortalitas (\%) } \\
\hline & & & alabio & cihateup \\
\hline \multirow[t]{2}{*}{$0-7$ hari } & Terbentuk selaput darah namun sedikit & Kekurangan nutrisi* & 8,71 & 28,38 \\
\hline & Busuk & Kontaminasi bakteri* & 0,35 & 2,70 \\
\hline \multirow[t]{2}{*}{ 8-25 hari } & Lemah & Suhu tinggi* & 6,27 & 51,61 \\
\hline & Busuk & Kontaminasi bakteri* & - & 48,39 \\
\hline \multirow[t]{6}{*}{ 26-28 hari } & Embrio lemah dan kering & Suhu tinggi*, kelembaban rendah* & 15,31 & 23,81 \\
\hline & Kuning telur di luar & Kekurangan nutrisi, suhu tinggi* & 2,44 & 14,29 \\
\hline & Bulu rontok & Kekurangan nutrisi* & 4,53 & 7,94 \\
\hline & Kelainan pada kaki dan kepala & Kekurangan nutrisi, genetik, suhu tinggi* & 1,05 & 14,29 \\
\hline & Organ rusak & Kontaminasi bakteri* & 4,53 & 11,11 \\
\hline & Kelainan pada paruh & Genetik/heredity, kekurangan nutrisi* & 1,39 & 11,11 \\
\hline
\end{tabular}

Sumber: * North and Bell (1990)

organ rusak dan kelainan pada organ (kaki, kepala, dan paruh) serta terdapat pula telur yang busuk. Ciri-ciri dari kematian embrio tersebut (bulu rontok dan kelainan pada organ) diduga akibat dari pertumbuhan embrio yang tidak sempurna karena kekurangan nutrisi. Hal tersebut sesuai dengan pendapat Lestari et al (2013) menyatakan telur mengandung nutrisi, seperti vitamin, mineral dan air yang dibutuhkan untuk pertumbuhan embrio. Pada telur yang busuk dan organ rusak disebabkan oleh kontaminasi bakteri (North and Bell 1990). Kontaminasi bakteri disebabkan karena kondisi kerabang telur yang kotor sehingga berpeluang masuknya bakteri ke dalam telur melalui poripori telur (Setioko 1992). Pada embrio yang lemah dan kering diduga karena suhu tinggi dan kelembaban rendah pada mesin tetas. Hal tersebut sesuai dengan pendapat Ningtyas (2013) menyatakan telur yang tidak menetas karena kekeringan disebabkan oleh kelembaban mesin tetas yang terlalu rendah dan suhu mesin yang tinggi pada masa akhir pengeraman.

\section{Bobot dan Indeks Telur}

Bobot telur dan indeks telur itik cihateup dan telur itik alabio didapatkan hasil yang tidak berbeda nyata antara telur yang menetas dan telur yang tidak menetas. Pengaruh bobot dan indeks telur pada kedua jenis telur itik disajikan pada Tabel 5 dan Tabel 6 .

Tabel 5 dan Tabel 6 menunjukkan bobot dan indeks telur itik tidak berpengaruh terhadap daya tetas, namun yang mempengaruhi daya tetas telur itik pada penelitian ini yaitu suhu tinggi yang terjadi selama penetasan, kelembaban rendah pada periode hatcher dan kebersihan kerabang telur. Hasil yang sama juga dilaporkan Setiadi (2000) yang menyatakan persentase daya tetas pada telur seleksi maupun kontrol tidak dipengaruhi oleh bobot dan indeks telur yang kecil, sedang, maupun besar. Penyusutan telur tetas pada penelitian ini tidak berbeda nyata $(\mathrm{P}>0,05)$ antara kedua jenis telur itik baik telur yang menetas maupun telur yang tidak menetas. Hasil yang sama juga didapatkan dalam penelitian yang dilakukan oleh Lestari et al. (2013) yang menginformasikan hasil pengukuran penyusutan bobot telur pada kedua jenis ternak (entog dan itik) tidak mengalami perbedaan sangat nyata pada telur yang memiliki bobot kecil, sedang, maupun besar.

Koefisien keragaman bobot telur dan indeks telur itik alabio dan telur itik cihateup yang menetas dan yang tidak menetas berukuran seragam ditandai oleh nilai koefisien keragamannya $<10 \%$. Menurut Dharma et al (2001), bobot telur dipengaruhi galur atau bangsa, umur induk, periode produksi (awal atau menjelang akhir), umur masak kelamin, besar tubuh, banyak telur yang dihasilkan dan kualitas pakan.

Bobot telur dan indeks telur itik cihateup yang digunakan pada penelitian ini nyata $(\mathrm{P}<0,05)$ lebih besar dari telur itik alabio. Bobot telur dan indeks itik pada kedua jenis telur itik disajikan pada Tabel 7 dan Tabel 8 .

Tabel 7 dan Tabel 8 menunjukkan telur tetas dari jenis itik yang berbeda yaitu telur tetas yang dihasilkan oleh itik alabio dan itik cihateup didapatkan perbedaan yang nyata antara bobot telur awal, bobot telur akhir, penyusutan 
Tabel 5 Bobot dan indeks telur itik alabio yang menetas dan tidak menetas

\begin{tabular}{lcccc}
\hline Telur alabio & \multicolumn{4}{c}{ Peubah } \\
\cline { 2 - 5 } & Bobot telur awal $(\mathrm{g})$ & Bobot telur akhir $(\mathrm{g})$ & Penyusutan Bobot telur $(\%)$ & Indeks $(\%)$ \\
\hline Menetas & $66,82 \pm 4,02$ & $59,52 \pm 4,06$ & $10,90 \pm 2,33$ & $78,09 \pm 3,32$ \\
& Kk:6,01\% & Kk:6,84\% & & Kk:4,26\% \\
Tidak menetas & $66,99 \pm 4,01$ & $59,64 \pm 3,82$ & $10,96 \pm 2,89$ & $77,80 \pm 3,09$ \\
& Kk:5,99\% & Kk:6,41\% & & Kk:3,97\% \\
\hline
\end{tabular}

$\mathrm{Kk}$ : koefisien keragaman.

Tabel 6 Bobot dan indeks telur itik cihateup yang menetas dan tidak menetas

\begin{tabular}{lcccc}
\hline Telur cihateup & \multicolumn{4}{c}{ Peubah } \\
\cline { 2 - 5 } & Bobot telur awal $(\mathrm{g})$ & Bobot telur akhir $(\mathrm{g})$ & Penyusutan Bobot telur $(\%)$ & Indeks $(\%)$ \\
\hline Menetas & $71,95 \pm 3,85$ & $63,94 \pm 3,68$ & $11,14 \pm 1,77$ & $80,17 \pm 3,31$ \\
& Kk:5,35\% & Kk:5,75\% & & Kk:4,13\% \\
Tidak menetas & $70,45 \pm 4,96$ & $61,93 \pm 4,03$ & $12,12 \pm 3,00$ & $80,66 \pm 4,37$ \\
& Kk:7,04\% & Kk:8,20\% & & Kk:5,42\% \\
\hline
\end{tabular}

Kk : koefisien keragaman.

Tabel 7 Bobot dan indeks telur itik yang menetas

\begin{tabular}{lcccc}
\hline \multirow{2}{*}{ Menetas } & \multicolumn{3}{c}{ Peubah } \\
\cline { 2 - 5 } & Bobot telur awal $(\mathrm{g})$ & Bobot telur akhir $(\mathrm{g})$ & Penyusutan Bobot telur $(\%)$ & Indeks $(\%)$ \\
\hline alabio & $66,82 \pm 4,02 \mathrm{a}$ & $59,52 \pm 4,06 \mathrm{a}$ & $10,90 \pm 2,33 \mathrm{a}$ & $78,09 \pm 3,32 \mathrm{a}$ \\
& $\mathrm{Kk}: 6,01 \%$ & $\mathrm{Kk}: 6,84 \%$ & $\mathrm{Kk}: 4,26 \%$ & $80,17 \pm 3,31 \mathrm{~b}$ \\
cihateup & $71,95 \pm 3,85 \mathrm{~b}$ & $63,94 \pm 3,68 \mathrm{~b}$ & $11,14 \pm 1,77 \mathrm{a}$ & $\mathrm{Kk}: 4,13 \%$ \\
& $\mathrm{Kk}: 5,35 \%$ & $\mathrm{Kk}: 5,75 \%$ & & \\
\hline
\end{tabular}

Keterangan: nilai disertai huruf yang berbeda dalam kolom yang sama menunjukkan perbedaan yang nyata $(\mathrm{P}<0,05), \mathrm{Kk}: \mathrm{koefisien}$ keragaman.

bobot telur dan indeks baik dari telur yang menetas dan telur yang tidak menetas. Bobot telur itik alabio termasuk ke dalam kelompok sedang. Rataan bobot telur itik cihateup termasuk ke dalam kelompok besar. Lasmini dan Heriyati (1992) menyatakan bahwa telur dengan bobot 71-80 g/butir termasuk ke dalam kelompok besar, sedangkan kelompok bobot 61-70 g/butir adalah sedang dan kelompok bobot 50 $60 \mathrm{~g} /$ butir adalah kecil.

Indeks bentuk telur itik alabio lebih panjang karena indeks telur yang didapat lebih rendah dari 79\%, sedangkan telur itik cihateup berbentuk lebih bulat karena indeks yang didapat lebih besar dari 79\%. Hal tersebut sesuai dengan pendapat Dharma et al. (2001) yang menyatakan nilai yang lebih kecil dari 79\% akan memberikan penampilan lebih panjang, sedangkan nilai yang lebih besar dari 79\% akan memberikan penampilan yang lebih bulat. Indeks telur mencerminkan bentuk telur yang sangat dipengaruhi oleh sifat genetik. Bobot dan indeks telur pada kedua jenis telur yang ditetaskan seragam ditandai oleh nilai koefisien keragamannya $<10 \%$.

\section{Hubungan Bobot Telur dengan Bobot Tetas}

Rataan bobot telur itik cihateup pada penelitian ini lebih tinggi dari telur itik alabio sehingga menghasilkan bobot tetas yang lebih tinggi pula. Hubungan bobot telur dengan bobot tetas DOD itik alabio dan itik cihateup disajikan pada Tabel 9.

Analisis regresi menunjukkan adanya hubungan antara bobot telur dan bobot tetas, semakin tinggi bobot telur yang ditetaskan akan menghasilkan bobot tetas yang lebih besar. Hal tersebut disebabkan oleh banyaknya nutrisi yang ada di dalam telur. Telur yang besar mengandung nutrisi yang lebih banyak dibandingkan telur yang berukuran kecil (Gunawan 2001).

Hubungan antara bobot telur dan bobot tetas itik alabio pada penelitian ini mengikuti persamaan regresi menunjukKan bahwa setiap peningkatan $1 \mathrm{~g}$ bobot telur (x) akan meningkatkan 0,56 g bobot tetas. Telur itik cihateup menunjukkan setiap kenaikan $1 \mathrm{~g}$ bobot telur (x), akan menyebabkan peningkatan $0,51 \mathrm{~g}$ bobot tetas. Nilai korelasi menunjukkan hubungan yang positif antara bobot tetas dengan bobot telur. Nilai koefisien determinasi telur itik alabio sebesar 39,40\% memiliki arti sebesar 39,40\% keragaman bobot tetas dipengaruhi oleh keragaman bobot telur atau sekitar 60,63\% keragaman bobot tetas dipengaruhi oleh faktor lain selain bobot telur, sedangkan pada telur itik cihateup nilai koefiisen determinasi sebesar 25,90\% memiliki arti 25,90\% keragaman bobot tetas dipengaruhi oleh keragaman bobot telur atau sekitar 74,1\% keragaman bobot tetas dipengaruhi oleh faktor lain selain bobot telur seperti suhu, kelembaban di dalam mesin tetas, dan lainlain.

\section{KESIMPULAN}

Daya tetas telur itik alabio lebih tinggi dari daya 
Tabel 8 Bobot dan indeks telur itik yang tidak menetas

\begin{tabular}{lcccc}
\hline Tidak menetas & \multicolumn{4}{c}{ Peubah } \\
\cline { 2 - 5 } & Bobot telur awal $(\mathrm{g})$ & Bobot telur akhir $(\mathrm{g})$ & Penyusutan Bobot telur $(\%)$ & Indeks $(\%)$ \\
\hline alabio & $66,99 \pm 4,01 \mathrm{a}$ & $59,64 \pm 3,82 \mathrm{a}$ & $10,96 \pm 2,89$ & $77,80 \pm 3,09 \mathrm{a}$ \\
& $\mathrm{Kk}: 5,99 \%$ & $\mathrm{Kk}: 6,41 \%$ & & $\mathrm{Kk}: 3,97 \%$ \\
cihateup & $70,45 \pm 4,96 \mathrm{~b}$ & $61,93 \pm 4,03 \mathrm{~b}$ & $12,12 \pm 3,00$ & $80,66 \pm 4,37 \mathrm{~b}$ \\
& $\mathrm{Kk}: 7,04 \%$ & $\mathrm{Kk}: 8,20 \%$ & & $\mathrm{Kk}: 5,42 \%$ \\
\hline
\end{tabular}

Keterangan: nilai disertai huruf yang berbeda dalam kolom yang sama menunjukkan perbedaan yang nyata $(\mathrm{P}<0,05), \mathrm{Kk}: \mathrm{koefisien}$ keragaman.

Tabel 9 Hubungan antara bobot telur dengan bobot tetas DOD itik alabio dan itik cihateup

\begin{tabular}{lccccc}
\hline Jenis telur & Bobot telur $(\mathrm{g})$ & Bobot tetas $(\mathrm{g})$ & Persamaan regresi & Koefisien Determinasi & Nilai Korelasi \\
\hline alabio & $66,85 \pm 4,04$ & $37,17 \pm 3,76$ & $\mathrm{Y}=1,68+0,56 \mathrm{X}$ & $39,4 \%$ & 0,627 \\
cihateup & $71,95 \pm 3,85$ & $42,47 \pm 3,91$ & $\mathrm{Y}=5,80+0,51 \mathrm{X}$ & $25,9 \%$ & 0,509 \\
\hline
\end{tabular}

tetas telur itik cihateup. Bobot dan indeks telur itik tidak berpengaruh terhadap daya tetas, namun yang mempengaruhi daya tetas telur itik pada penelitian ini yaitu suhu tinggi yang terjadi selama proses penetasan, kelembaban rendah pada periode hatcher dan kebersihan kerabang telur. Kematian embrio selama proses penetasan paling banyak terjadi pada hari ke 0-7 dan hari ke 26-28. Bobot telur itik alabio dan telur itik cihateup berpengaruh terhadap bobot tetas. Analisis regresi menunjukkan adanya hubungan antara bobot telur dan bobot tetas. Nilai korelasi menunjukkan hubungan yang positif antara bobot tetas dengan bobot telur. Semakin besar ukuran telur akan menghasilkan bobot tetas yang besar pula.

\section{DAFTAR PUSTAKA}

Dharma YK, Rukmiasih, Hardjosworo PS. 2001. Ciri-ciri fisik telur tetas itik Mandalung dan rasio jantan dengan betina yang dihasilkan [Internet]. Bogor (ID): Institut Pertanian Bogor; [diunduh 2012 Feb 06]. Tersedia pada: http://repository.ipb.ac.id

[Dirjenak dan Keswan] Direktorat Jenderal Peternakan dan Kesehatan Hewan. 2012. Statistik Peternakan dan Kesehatan Hewan 2012. Jakarta (ID): Direktorat Jendral Peternakan dan Kesehatan Hewan.

Fujiwati WD, Sujana E, Darana S. 2012. Pengaruh konsentrasi asap cair tempurung kelapa pada fumigasi telur itik terhadap daya tetas dan kematian embrio[skripsi]. Jatinangor (ID): Universitas Padjadjaran.

Gazali M. 2001. Kriopreservasi semen entok dalam upaya produksi itik serati menggunakan teknologi inseminasi buatan [tesis]. Bogor (ID): Institut Pertanian Bogor.

Gunawan H. 2001. Pengaruh bobot telur terhadap daya tetas serta hubungan antara bobot telur dan bobot tetas itik mojosari [skripsi].Bogor (ID): Institut Pertanian Bogor.

Hermawan A. 2000. Pengaruh bobot dan indeks telur terhadap jenis kelamin anak ayam kampung pada saat menetas [skripsi].Bogor (ID): Institut Pertanian Bogor.

Kortlang CFHF. 1985. The incubation of duck egg. In: Duck Production Science and World Practice. Farrell DJ, Stapleton P, Editor. London (GB): University of
New England.p 168-177.

Lasmini AR, Abdulsamie, Purwati NM. 1992. Pengaruh cara penetasan terhadap daya tetas telur itik Tegal dan Alabio. Seminar Nasional Sains dan Teknologi. Balai Penelitian Ternak Ciawi;1992 Feb 20-22; Bogor, Indonesia. Bogor (ID): 31-34.

Lasmini A, Heriyati E. 1992. Pengaruh berat telur terhadap fertilitas, daya tetas dan berat tetas DOD Pengelolaan dan Komunikasi Hasil-hasil Penelitian Unggas dan Aneka Ternak. Balai Penelitian Ternak Ciawi;1992 Feb 20-22; Bogor, Indonesia. Bogor (ID): 35-37.

Lestari E, Ismoyowati, Sukardi. 2013. Korelasi antara bobot telur dengan bobot tetas dan perbedaan susut bobot pada telur entok (Cairrina Moschata) dan itik (Anas Plathyrhinchos). J Ilmiah Petern.1(1):163-169.

Matitaputty PR. 2012. Peningkatan produksi karkas dan kualitas daging itik melalui persilangan antara itik Cihateup dengan itik Alabio [disertasi]. Bogor (ID): Institut Pertanian Bogor.

Mattjik AA, Sumertajaya IM. 2002. Perancangan Percobaan dengan Aplikasi SAS dan Minitab.Bogor (ID): IPB Pr.

Muzani A, Brahmantiyo B, Sumantri C, Tapyadi A. 2005. Pendugaan jarak genetik pada itik cihateup, cirebon dan mojosari. Media Petern. 28 (3): 109-116.doi: ISSN 0126-0472.

North MO, Bell DD. 1990. Commercial Chicken Production Manual Fourth Edition. An Avia Book Published by Van Nostrand. New York (US): Reinhold.p 763-773

Nuryati T, Sutarto, Khamim M, Hardjosworo PS. 2000. Sukses Menetaskan Telur. Jakarta (ID): Penebar Swadaya.

Rohaeni ES, Subhan A, Setioko AR. 2005. Usaha penetasan itik alabio sistem sekam yang dimodifikasi di sentra pembibitan kabupaten Hulu Sungai Utara. Seminar Nasional Teknologi Peternakan dan Veteriner [Internet]. [2005 Sep 12-13; Bogor, Indonesia]. Bogor (ID): Puslitbang Peternakan. [diunduh 2013 Mei 15]. Tersedia pada: http ://peternakan.litbang.deptan.go.id/ fullteks/semnas/pro05-121.pdf.

Setiadi P, Lasmini A, Setioko AR, Sinurat AP. 1992. Pengujian metode penetasan telur itik tegal di 
pedesaan. Pengolahan dan Komunikasi Hasil-hasil Penelitian. Unggas dan Aneka Ternak;1992 Feb 20-22; Bogor, Indonesia. Bogor (ID): hlm 38-42.

Setiadi P. 2000. Pengaruh indeks bentuk telur terhadap persentase kematian embrio, gagal tetas, dan DOD cacat pada telur itik Tegal yang di seleksi. Anim Prod. 2(1):25-32.

Setioko AR. 1992. Teknik penetasan telur itik. Aplikasi Teknologi Bidang Peternakan. Badan Litbang Pertanian. hlm. 142-152.

Steel RG, Torrie JH. 1995. Prinsip dan Prosedur Statistik. Sumantri B, editor. Jakarta (ID): Penerbit Gramedia Pustaka Utama. Terjamahan dari: Principles and procedures of statistics.

Supriyadi MM. 2011. Panduan Itik. [Internet]. [diunduh 2012 Mei 12]. Tersedia pada: http://cybex.deptan. go.id/penyuluhan/jenis-itik-cihateup.

Suretno ND. 2006. Kajian produktifitas dan fertilitas itik cihateup [tesis]. Bogor (ID): Institut Pertanian Bogor.

Wulandari A. 2002. Pengaruh indeks dan bobot telur itik tegal terhadap daya tetas, kematian embrio dan hasil tetas [skripsi]. Purwokerto (ID): Universitas Jenderal Soedirman. 